\title{
The Academic Design/Build: A Model of Mutual Aid and Product/Process Integrity
}

TRAVIS BELL

Portland State University

\begin{abstract}
The academic design/build project eschews the typical economic model for architectural project delivery in critical ways and in so doing offers a unique opportunity to demonstrate an alternative perspective on architecture's role in society. Through a focus on mutual aid, as an organizational scheme, the academic design/build project can position architecture as a series of interrelated acts of voluntary gratitude; a learning tool, a method of production, a public service, a product and a process.
\end{abstract}

\section{INTRODUCTION \& HISTORICAL CONTEXT}

The academic design/build project, due to the de-emphasizing of the product and the over-emphasizing of the methods of production, is less an example of architecture as economic activity and more an example of architecture as communal activity. To envision architecture as communal activity is, many would argue, a vast improvement over its rather cold formulation as a purely functional sector of economic activity; something akin to roads, power-grids and general infrastructure. More critically, to envision architecture as communal activity offers the possibility of its significance as a form of community in and of itself; this conception is broader and more inclusive than the increasingly common perception of architecture as power made visible in material form (architecture as a tool for the 1\%).

Questions involving the artistic and social integrity of architecture have been a common theme in 20th century critical theory. Marxist critiques of artistic production directly deny that such a thing can exist within capitalism pointing to the lack of artistic and social agency within capitalized methods of production. Walter Benjamin preferred discussing the aura of a work of art as opposed to its integrity. For Benjamin, the aura of a work of art included concepts like integrity but also further aspects of the art like its cultural significance and aesthetic merits. Benjamin proposed that the aura of a work of art is directly related to it's methods of production, in time and space, and thus reproductions would never be capable of reclaiming analogous significance. Paul Ricoeur proposed similar issues confronting the integrity of human identity and of the artifacts that support such identity within globalized systems of production and capitalization. More contemporary architectural theorists, most notably Kenneth Frampton, have continued this focus on the methods of production as the critical feature of architectural integrity and cultural significance. Throughout this long-standing discourse, we are asked to consider the central importance of the control of the methods of production upon artistic and architectural integrity. We are also asked to consider the relationship between communal methods of production and authentic cultural significance.

\section{MUTUAL AID}

This paper argues that the foundational concept in envisioning architecture as a form of communal activity is seeing the methods of production, as well as the final products, as acts of mutual aid between various members and organizations within the community. There are many ways to pedagogically and economically structure an academic design/build project, but few will nurture academic integrity and product integrity as effectively as one built on the concept of mutual aid. The integrity of this sort of structure seems to arise from the ability to consistently frame productive efforts as gifts, freely given, to one another for collective gain and thus resistant to corruption.

Mutual aid is a socio/economic concept that comes to us from varied examples of guilds, unions and workers clubs, many with anarchist leanings, that placed high value on individual agency within society. It is conceived as an alternative rationale for driving the lively exchange of goods and services that constitute an economy. Rather than a purely capitalist exchange of money for goods and services, the notion of mutual aid envisions a gracious sharing of help between individuals, such that all parties receive compensation for their participation in community life. This compensation might be monetary but it also acknowledges the robust possibilities involved in the trading of services, goods and labor. At the heart of the idea that people might willingly exchange help to one another in lieu of money is an acknowledgement that money is simply a proxy for one's promise to give aid in exchange for taking it. We give to others not only for the pleasure of doing so, but because we know that one day we too will require it. In theory, communities built on the expectation of mutual aid are able to operate perfectly well without the need for large amounts of capital to fund community projects.

A community organized around the principal of mutual aid might seem far too academic to merit serious consideration in our globally capitalized world. Further, the suggestion that such a method of economy has any serious consideration within the immensely capitalized world of modern architecture and construction seems outright dimwitted. I will 


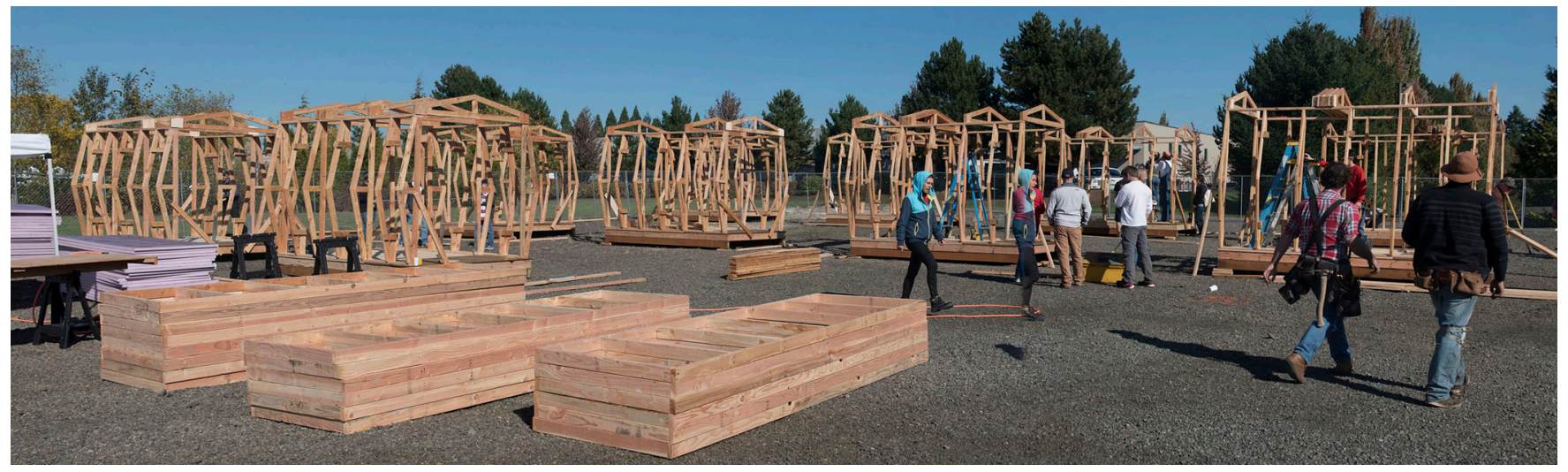

Figure 1: Wooden trusses being utilized in their final iteration as the structural frame for new homeless sleeping PODs.

acquiesce to these criticisms in regards to how architecture and the act building currently function in Western society. I would submit however that the academic design/build project - by far the academy's most effective method of teaching future architects how to build and how to design things that will eventually get built - along with the economic structure of much of non-western society, exists in a sort of shadow economy that struggles to find capital, is flush with talented, inquisitive labor and which operates most effectively within precisely the sort of non-monetary system of barter, sharing, and mutual benefit that underpins the economic concept of mutual aid. In my experience, and those of my colleagues, the productive output, educational priorities, project budget and construction timelines that characterize the academic design/build simply do not align well with capitalized projects. Put more simply, academic architecture has difficulty playing by the same rules as capitalist architecture. The product becomes the focus and the process is degraded.

Despite this issue of misalignment between the economy and the academy, I still believe design/build projects are the most desirable method of teaching future architects the skills and knowledge needed to manipulate our shared/built environment. This acknowledgement urges us to consider, and share with one another, examples of successful systems of economy and methods of production \& delivery that work despite being different then those of the dominant economy. I would like to share a few thoughts on a design/build studio we've been slowing evolving at Portland State University's School of Architecture called the Diversion Design/Build Studio. Our studio, through five years of project cycles, has been slowing moving towards a design/build pedagogy that explicitly structures models of mutual aid into our methods of production, project management and overall design process. What follows is a series of topical descriptions of the Diversion Design/Build Studio with particular emphasis on our most recent project, the 2017 Treeline Stage. Under the model of mutual aid, particular methods and organizational structures have suggested themselves in regards to our products and processes. Indeed, the nature of the relationship between product/process is directly impacted, in positive ways, by the decision to explore this sort of organizational structure. The 2017 Treeline Stage is our best example to date of multiple stakeholders attaining separate, individual goals through shared effort and mutual benefit. It is a unique project that has allowed each stakeholder full agency of their respective products and processes while simultaneously aiding other stakeholders to attain desired outcomes. A larger, more diverse pool of stakeholders has been essential in formulating this model of mutual aid. By helping one another, we have each helped ourselves.

\section{THE DIVERSION DESIGN/BUILD STUDIO}

The Diversion Design/Build Studio at Portland State University's School of Architecture, created in collaboration with my colleague Professor Clive Knights, is a student-led design experiment aimed at exploring the rich experiential qualities of architecture through the design and realization of temporary celebratory spaces while simultaneously exploring the value of responsible/ethical design practice. We've called this experiment the Diversion Design/Build Studio referencing two core strategies of our work; (1) the diversion of non-typical, re-useable, and dual-purpose industrial materials/components for use in temporary construction and (2) the diversion toward non-typical experiences like those embodied in festival gathering.

Over the past 6 years (the 6th project beginning this Spring), the Diversion Design/Build Studio has partnered with the Pickathon Music Festival, an annual event that takes place over 4 days in August at Pendarvis Farm, Happy Valley, Oregon, to explore these sorts of temporary celebratory spaces and material strategies. Pickathon has been at the leading edge of a growing number of arts organizations committed to the idea that collective gathering around the arts, particularly festivals, need not require an enormous carbon footprint... it requires thoughtful design. The Pickathon story involves a constant re-thinking about the way we use materials and how we might minimize this consumption. These efforts have placed Pickathon as a world leader in the sustainable festival 


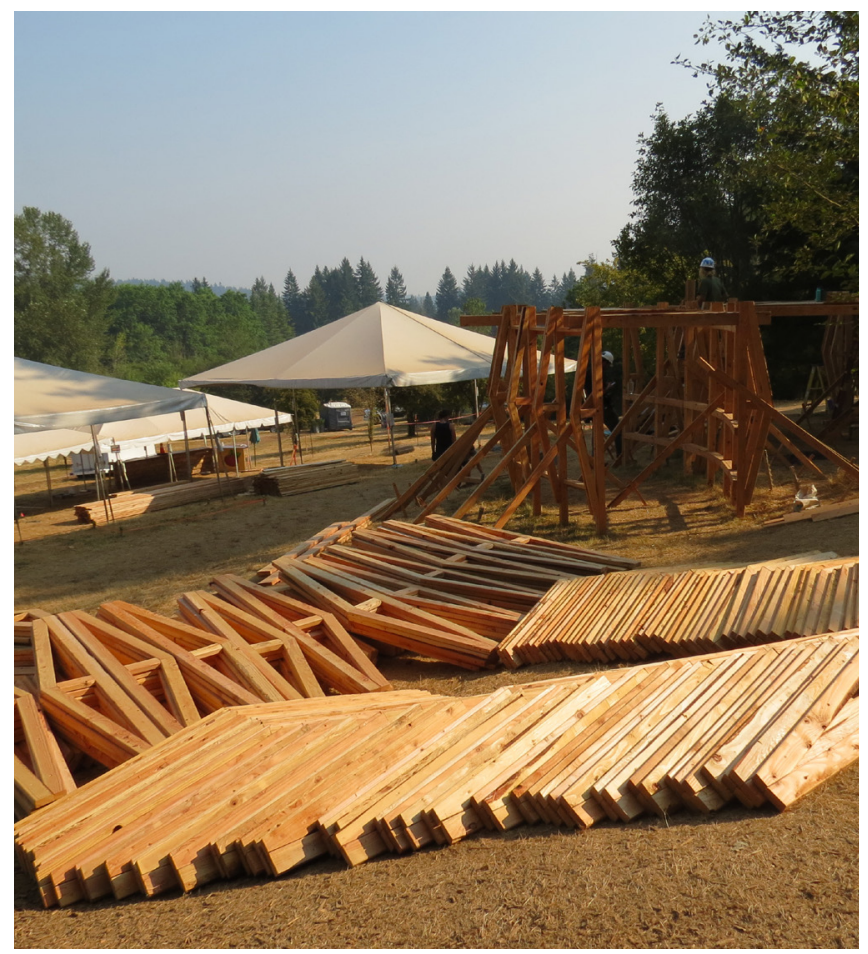

Figure 2: Wooden trusses, consturcted by students, being used in thier intial iteration as part of a temporary, outdoor performance venue.

movement. The Diversion Design/Build Studio has been a key collaborator in exploring this shared mission.

The Diversion Design/Build Studio is structured over 6 months, broken into two distinct phases: a design-specific course for graduate students taking place in the Spring term ( 2 credits) and a shorter, more intense construction-specific course for graduates and undergraduates taking place over 4 weeks in the summer term ( 4 credits). The design phase is structured in the manner of a small practice, with client meetings, consultant meetings, volunteer meetings, and close collaboration with the festival site manager in coordinating the tight, preordained installation period. With very little funding, material availability drove initial investigations with the goal of discovering a local, industrial surplus material or waste product from which a design could be inspired. After much research, the studio landed upon the concept of the temporary re-purposing, or diverting, of a prefabricated, modular entity that could be used as a 'building block,' but not used-up.

Our past projects have focused on designing temporary performance spaces out of materials that can be returned, unscathed, to their respective industrial cycles. These performance venues have all carried the same name: The Treeline Stage. Each stage is different from year to year in terms of its design and materiality, but the location, design process, and teaching \& management responsibilities remain consistent. Our goal in past projects was to design a zero waste architecture that carefully choreographed both the construction and de-construction processes so that all materials could be returned to service at the completion of their temporary use. Through these projects we were able to formulate a process that allowed for striking architecture that was in full control of it's environmental footprint.

For our 5th project, the Diversion Design/Build Studio aimed to extend the reach of our efforts and to increase the social ambitions of the project. While past projects have been intended to minimize the environmental impact of the construction, the 2017 project was intended to maximize impact, both socially and materially, by introducing the concept of pre-use design. In pre-use design, we focus our initial creative energy on identifying building components that might be needed for unrelated, underfunded projects that serve a meaningful public good. This process involves critical collaboration with PSU's Center for Public Interest Design (CPID) to help identify worthy projects. As a faculty fellow at the CPID I have been able to pilot this sort of pre-use design process. Our central question at this initial stage is how might the design/build efforts of our students be mutually beneficial to both Pickathon and our additional partnering organization/project? This is a creative design effort all it's own and one we feel is greatly undervalued in current design practice. Once the building components have been identified, we explore how we might align the needs of one project to benefit another. Typically we are searching for how we might produce the maximum quantity of building components for pre-use in our temporary design/build projects and thus maximize the benefits to our permanent, partnering projects. As the designated type and quantity of building component(s) for use in the final, permanent project are being considered, our team of students and faculty begin exploring how we might use these components as the building blocks for the temporary performance venue at Pickathon. In many ways, this is the ideal of sustainability-not just to keep one's use of materials to a minimum, but to find ways to make our use of materials mean more, create more, and actually have a positive social and environmental impact on the world, through innovative design combined with compassion for those in need. Our current project is diverting energetic surplus in addition to material surplus - we are diverting good will, human effort, and design.

These efforts have resulted in what we feel are exciting and innovative projects both architecturally and in response to the issues of material re-use, sustainable design, public service, and the enrichment of human experience.

\section{FUNDING \& SPONSORSHIP}

As mentioned previously, academic design/build projects are typically flush with various forms of volunteer labor and thus it is the cost of materials that drive project feasibility. In my experience, grant funding for construction materials has been 


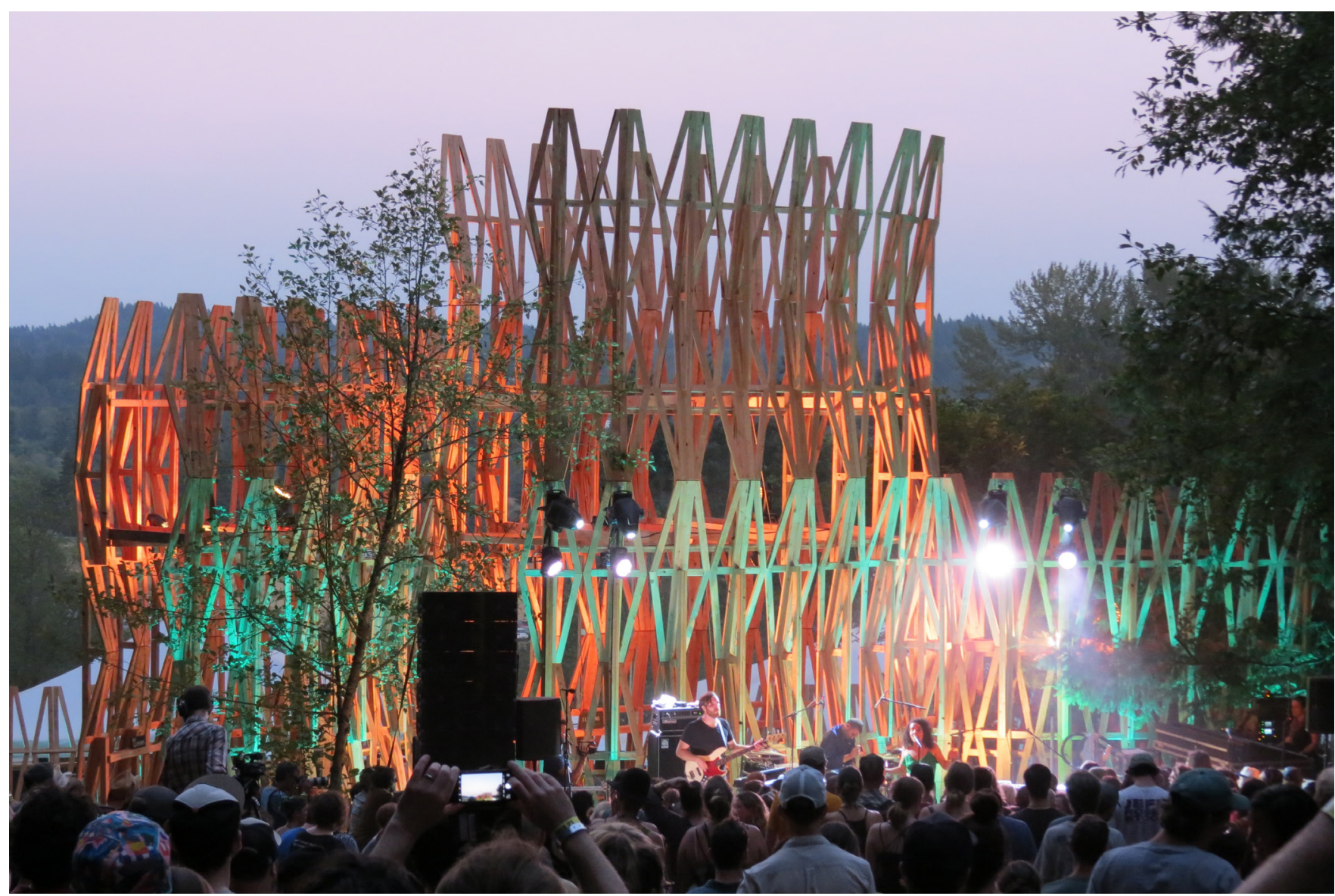

Figure 3: The 2017 Treeline Stage in use during the Picakthon Music Festival.

difficult to find and I have thus focused my efforts on procuring local funding via project sponsorship.

Each of the projects undertaken by the Diversion Design/ Build Studio has received full project sponsorship, from outside the university, for building materials and construction equipment. This material sponsorship comes from a variety of sources with the two primary sources being Pickathon and a local construction contracting company, Lease Crutcher Lewis. Further sponsorship comes in the form volunteer design consultation from local professional practice; including various architecture firms, structural engineering firms, and lighting designers. Construction labor for our projects is based entirely on student course-work expectations and substantial volunteer labor from an enthusiastic volunteer pool that includes members of local architectural practice, alumni from past Diversion Design/Build projects, alumni from the School of Architecture, and volunteers from Pickathon's community network. I have been actively nurturing this volunteer pool over my $5+$ years at PSU, along with local contacts made over $10+$ years of architectural practice within our community. This volunteer pool is an extremely valuable resource that requires time and effort to maintain and grow. Collectively, these various forms of sponsorship (both monetary and monetary-equivalent volunteer efforts) make up a network of local sponsorship that has been critical to the success of the Diversion Design/Build Studio.

Total project sponsorship only accounts for the specific scope of work undertaken by the Diversion Design/Build Studio (materials, design costs, and construction costs for the architecture). Every one of our projects contains additional design and construction work in order to create a functioning performance space. This additional project scope, (including sound equipment, lighting equipment, electrical routing, staging, stage rigging, etc.) adds overall value to our projects in excess of $\$ 50,000$ per project, according to our collaborators at Pickathon. These additional costs are substantial and allow for the student's work to exist within a far more comprehensive and functional reality. In essence, the Diversion Design/Build projects have allowed our students to design $\&$ build works of experimental architecture that carry total project values ranging from $\$ 50,000-\$ 100,000$; they have been given the opportunity to make tangible architecture as part of their education. This caliber of student experience is rare and something I am particularly proud of.

\section{INNOVATION}

The Diversion Design/Build Studio's innovation, as educational pedagogy, as public service, and as design process stems from it's embrace of multiplicity. 


\section{FROM STAGE TO SHELTER}

\section{PHASE I TREELINE STAGE}

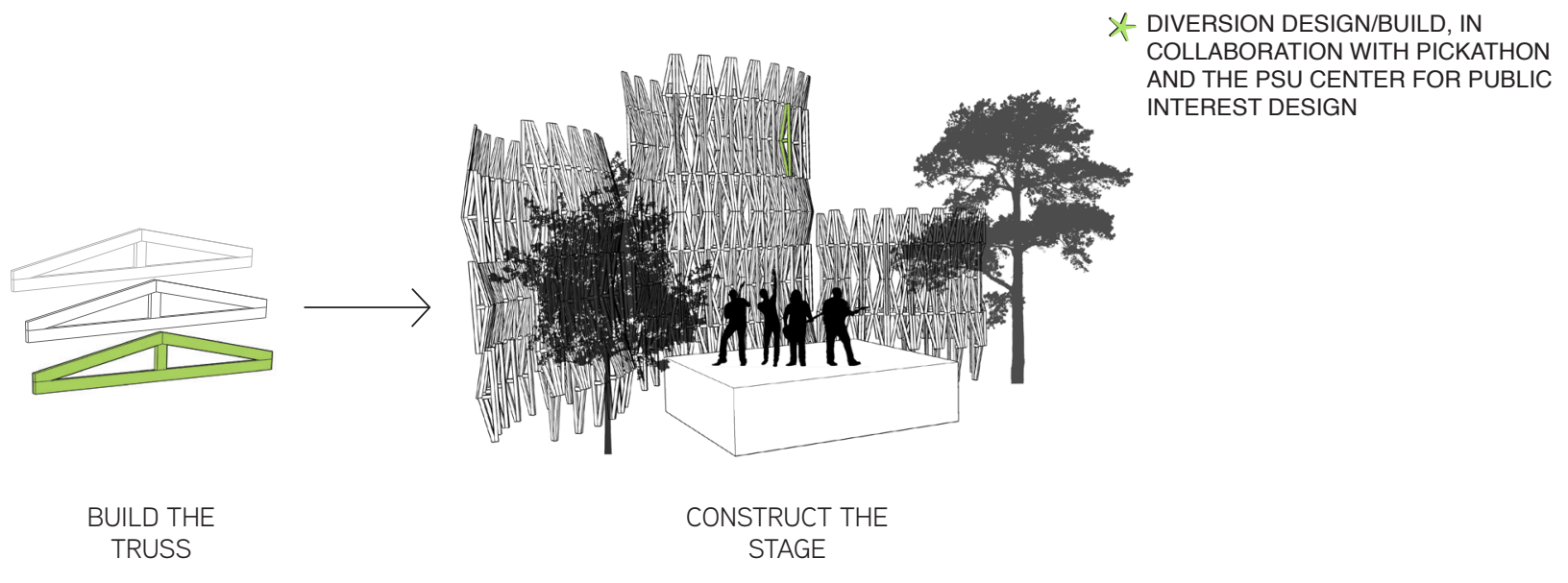

PHASE II POD CONSTRUCTION

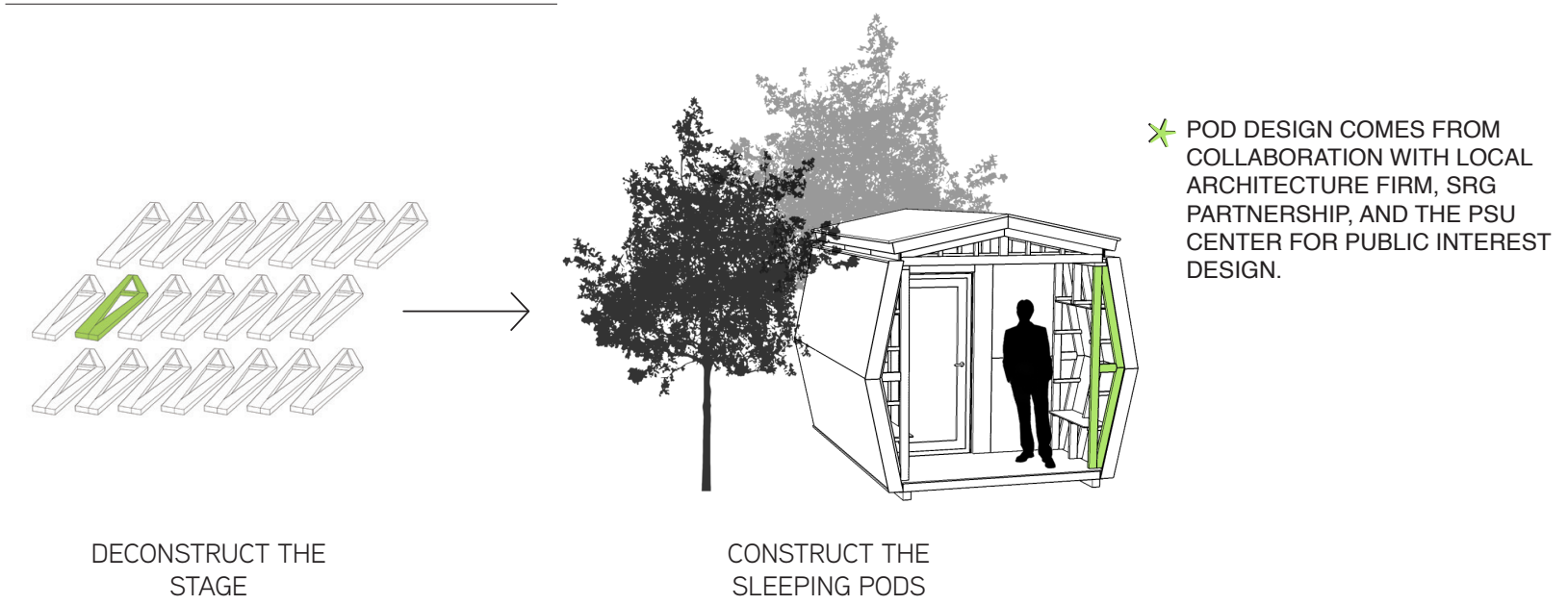

PHASE III HOUSELESS VILLAGE

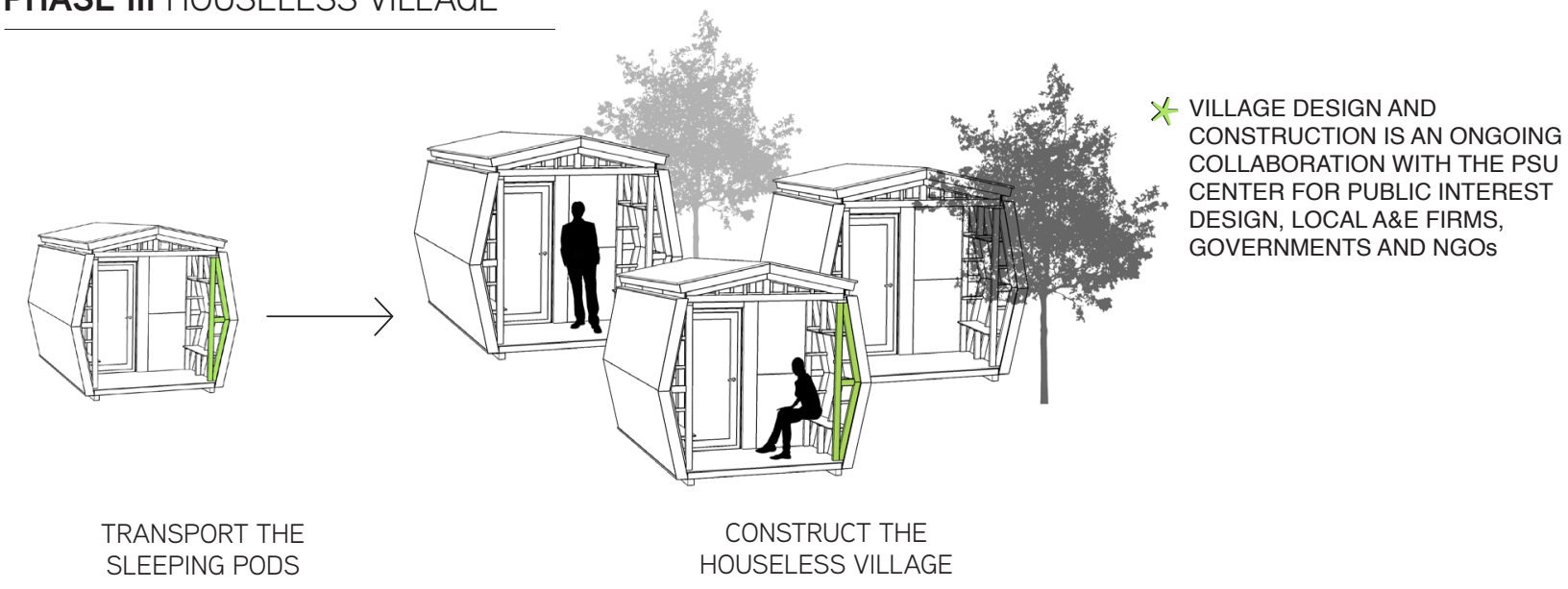

Figure 4: Graphic depicting the various uses of the same wooden trusses.

Mutual aid can stretch humble budgets and offer creative synergies. 
Our projects are both temporary and permanent. The temporary aspects of our work, the festival performance spaces, allow for greater experimentation as we can be freed from the restraints that govern the longer-term examples of the build environment (i.e. buildings and their respective codes and zoning requirements). This design freedom is incredibly valuable to our students. Each year they are charged with imaginatively addressing the capacity for architecture to enhance and transform the festival-goers musical experience; to make a stage setting that in itself is a critique of the typical, banal kit-of-parts that dominates every other music festival. The permanent aspect of our work, however, e.g. the homeless sleeping pod village from the 2017 project, does require a more conservative design/build approach (i.e. leaner budget designated for design, more design constraints, more stakeholders, etc.) but these constraints can be appreciated rather than maligned. For the permanent work, our students have an opportunity to work through the complicated process of building codes and officials, modifying the scope and effect of what is essentially the same construction component.

Our materials and components are used in a variety of cooperative schemes. Designing for multiple possibilities is an added burden at first blush, however, we often find that constraints can be the designer's best friend as they strip out unnecessary criteria, allowing the imagination to flourish through focus on a discreet set of design issues.

Our clients/users are specific and diverse. Multiple users can often make our designs more human; more attuned to what makes us part of the same species. At the same time, specific places and users are full of critical details that make a piece of architecture special. In this case we are given the opportunity to design around specific goals for each client/ user but these goals have to remain empathetic towards the other collaborative uses.

Our projects have multiple stakeholders working to achieve our goals through mutual aid. The 2017 Treeline Stage, our most recent project, is an educational project for teaching future architects, a semi-public installation exploring new kinds of built space, and a public project used to supply social services for local governments and NGOs. Each stakeholder offers incentives for the other stakeholders. The School of Architecture gains access to funding and a public space to create experimental architecture designed and built by students. This work is difficult to fund because students are still learning their craft and thus cannot reliably align cost and durability expectations with those of professionals who are building permanent work. Pickathon gains a unique and purposedesigned performance venue for its music festival at very little cost...something important for a temporary gathering. Our government and social service partners gain hundreds of hours of volunteer time and lively public engagement with their various strategies of tactical urbanism. Our students receive tickets to the music festival, are fed throughout the construction and de-construction of the festival by Pickathon and are treated with deep gratitude by all attendees for their efforts. Finally, they have been given the opportunity to make tangible architecture, with total project costs between $\$ 50,000-\$ 100,000$, as part of their education. Everyone gives something and receives something in return.

The Diversion Design/Build Studio's strength is in its willingness to accept these multiple situations all at once. It is experimental and pragmatic; playful and responsible.

\section{IMPACT}

These projects have had broad positive impact with a large and varied audience.

Portland State University, the School of Architecture and PSU's Center for Public Interest Design have all received accolades for the 2017 Diversion Design/Build project and continue to field questions about the project and its story from publications, students, and community members. Past projects have had similarly positive accolades from the Portland arts and architecture community. The 2017 and 2015 projects both received jury awards at the Annual Portland AIA Design Awards (American Institute of Architects). The 2017 Diversion Design/Build project also received a design award from Gray Magazine. These sorts of peer-reviewed awards for built-work are rare achievements for student design/build projects.

The 2017 Diversion Design/Build project was able to bring together The City of Portland and Clackamas County in a joint project addressing the growing issue of homelessness in our community. Both local governments have expressed gratitude and a certain amount of amazement that this project was able to become a reality. We have the impression that these local governments are not used to receiving large volunteer-led projects as a gift from the community.

Local homeless advocates, City Repair, the Village Coalition and Catholic Charities, have been delighted to receive the volunteer help, but the opportunity to create broader public awareness and advocacy of the issues surrounding homelessness via our design-build project has been a particularly exciting aspect for them. Making the issue of homelessness an ever-present and meaningful theme at the 2017 Pickathon Festival was a unique experience for these local organizations.

Finally, Pickathon has had the unique opportunity to broaden its goal of being the most responsible music festival in the world. Pickathon has been one of the global leaders in making an environmentally responsible temporary gathering for thousands of music lovers. In a similar trajectory to the Diversion Design/Build Studio, Pickathon began its efforts to carry the full responsibility of its festival planning 
by minimizing environmental impacts. Now, Pickathon, in collaboration with the Diversion Design/Build Studio, is demonstrating how temporary infrastructure can not only manage environmental impacts and remain enticing and beautiful...it can also turn these temporary celebrations into enduring improvements to our local, built environment and social fabric.

With the 2017 Treeline Stage, the emphasis of the Diversion Design/Build Studio has evolved from low-impact to highimpact and we intend to celebrate this evolution moving forward. We are now investigating how our design process explicitly engages local governments and NGOs as the final recipients of our design/build efforts, all while continuing to celebrate the experimentation of architectural form and space.

\section{IMPACT}

This project has had broad positive impact with a large and varied audience.

Portland State University, the School of Architecture and the school's Center for Public Interest Design have all received accolades for the work and continue to field questions about the project and its story from publications, students, and community members.

The City of Portland and Clackamas County have both expressed gratitude and a certain amount of amazement that this project was able to become a reality. We have the impression that these local governments are not used to receiving large volunteer-led projects as a gift from the community. They have been wonderful.

Local homeless advocates, City Repair, the Village Coalition and Catholic Charities, have been delighted to receive the volunteer help, but the opportunity to create broader public awareness and advocacy of the issues surrounding homelessness via our design-build project has been a particularly exciting aspect for them. Making the issue of homelessness an ever-present and meaningful theme at Pickathon was a unique experience for these local organizations.

Finally, Pickathon has had the unique opportunity to broaden its goal of being the most responsible music festival in the world. Pickathon has been one of the global leaders in making an environmentally responsible temporary gathering for thousands of music lovers. In a similar trajectory to the Diversion Design-build Studio, Pickathon began its efforts to carry the full responsibility of its festival planning by minimizing environmental impacts (no single-use anything, free water, bike commuting, etc.). The next level of social responsibility for Pickathon could be seen in the ever-diversifying array of artists that are scheduled. The gender and cultural diversity present (by \%) in the musical line-up at Pickathon has been notable amongst most large national music festivals. Now Pickathon, in collaboration with the Diversion Design-build Studio, is demonstrating how temporary infrastructure can not only manage environmental impacts and remain enticing and beautiful...it can also turn these temporary celebrations into enduring improvements to our local, built environment and social fabric.

With the 2017 Treeline Stage, the emphasis of the Diversion Design-build Studio has evolved from low-impact to highimpact and we intend to celebrate this evolution moving forward. We are now investigating how our design process explicitly engages local governments and NGOs as the final recipients of our design-build efforts, all while continuing to celebrate the experimentation of architectural form and space.

\section{ENDNOTES}

1 Brian Grazer and Charles Fishman, A Curious Mind: The Secret to a Bigger Life (New York: Simon \& Schuster, 2015), 12.

2 Henry David Thoreau, "Walking," in The Making of the American Essay, ed. John D’Agata (Minneapolis: Graywolf Press, 2016), 177-78.

3 Grazer and Fishman, Curious Mind, 37.

4 Philip B. Kurland and Ralph Lerner, eds., The Founders' Constitution (Chicago: University of Chicago Press, 1987), chap. 10, doc. 19, http://press-pubs. uchicago.edu/founders/.

5 Susan Satterfield, "Livy and the Pax Deum," Classical Philology 111, no. 2 (April 2016): 170.

6 Kurland and Lerner, Founders' Constitution, chap. 4, doc. 29.

7 Thoreau, "Walking," 182.

8 "Privacy Policy," Privacy \& Terms, Google, last modified April 17, 2017, https:// www.google.com/policies/privacy/. 